\title{
The Economics of Institutions, Equity, Efficiency and Effectiveness: The Case of Water Distribution in Lower Sundays River Valley, South Africa
}

\author{
Patricia Kefilwe Madigele ${ }^{1}$ \\ ${ }^{1}$ Okavango Research Institute, University of Botswana, Maun, Botswana \\ Correspondence: Patricia Kefilwe Madigele, Okavango Research Institute, University of Botswana, P/Bag 285, \\ Maun, Botswana. E-mail: pmadigele@ori.ub.bw
}

Received: February 28, 2017

Accepted: May 3, 2017

Online Published: May 31, 2017

doi:10.5539/enrr.v7n2p98

URL: https://doi.org/10.5539/enrr.v7n2p98

\begin{abstract}
Water supply disruptions are prevalent in various parts of South Africa. The Lower Sundays River Valley is not an exception. However, there is currently no physical shortage of water in the catchment. This study defines institutional arrangements and dynamics in the water sector in South Africa, using the Lower Sunday River Water Users Association as the case study. Key informant interviews reveal that relevant stakeholders are not adequately represented in management committees. Such institutional arrangement vacuums can lead to a failure of the water institutions in the catchment to provide water resources effectively.
\end{abstract}

Keywords: institutions, efficiency, equity, effectiveness, new institutional economics; Lower Sundays River Valley; South Africa

\section{Introduction}

The need for water management and allocation policies and legislation that advocate for equitable distribution, sustainability and efficiency of water resources has prompted the South African government to undertake massive reforms and policy restructuring since 1994. Such legislation was conceived in the form of the Water Services Act of 1997 and the National Water Act of 1998. The key mandate of both pieces of legislation was to address socioeconomic problems such as rural poverty and high levels of inequality that were inherited from the apartheid regime. This was done through promoting equity and sustainability in water management, and by accommodating developments in the sector such as local, provincial and national institutions (Perret, 2002).

The government aims to maintain equity, sustainability and efficiency in the water sector through various centralised and decentralised institutions. The institutions operate at different levels of the water sector towards a common cause "to ensure that water is distributed, conserved, used, protected and allocated efficiently for the benefit of all" (RSA, 1998). This paper provides an in-depth analysis of the Lower Sundays River Water Users Association (LSR-WUA) as an institution operating at the local level.

The paper outlines the most notable historical events, which have contributed significantly to the current operations of the Association. The analysis is crucial in describing the influence of the existing institutional and water governance arrangements, and economic dynamics in the Lower Sundays River Valley in the efficiency, effectiveness and equity of water allocation in the catchment.

\section{New Institutional Economics at a Glance}

The emergence of a large range of academic work on multidisciplinary research regarding environmental and natural resource management issues such as environmental policies, natural resource scarcity and resource conflicts has increasingly diverted the focus of environmental economists from the neoclassical approach (Leach et al., 1999; Deacon \& Mueller, 2006; Hackett, 2011). Scholars now seek clarity on how institutions influence public choice, transaction costs and human behaviour from an institutional economics point of view (Leach et al., 1999; Deacon \& Mueller, 2006).

Efficient economic and resource management forms the foundation of new institutional economics. According to new institutional economics scholars, the discipline is centred on the need to align various imperfect institutional and contractual arrangements in order to determine the most suitable way to offset conflict and maximise the 
benefits of resource use with the least transactions cost (Gardner et al., 1994; Brousseau \& Glachant, 2002; Lieberherr, 2009). New institutionalism hence argues that the institutional environment should lay a foundation that enables the attainment of efficiency in institutional arrangements through the provision of structures that allow for collaboration and cooperation (Brousseau \& Glachant, 2002; Ostrom, 2004; Menard \& Shirley, 2005; Kirsten et al., 2009).

Institutions are viewed as cost-minimising and interdependent arrangements that form part of the complex economic system. According to Ollila (2009), economic agents either have divergent or convergent interests with respect to scarce resources, and hence they are interdependent. They have relationships through the natural resource base they depend on, and through institutions that govern their actions. By virtue of being interdependent, the choice of one economic agent has a direct influence on that of another agent (Paavola \& Adger, 2002).

New institutional economists argue that individuals on their own cannot appreciate how conflicting their interests are towards a specified scarce environmental and/or natural resource (Challen, 2000; Paavola \& Adger, 2002). Therefore, there is a need to define environmental management guidelines as well as to define private property rights, a concept known as the Coase Theorem. Such an exercise normally entails incurring transaction costs. The Coasian viewpoint is that property rights are essential for affirming the ultimate control over resources since transaction costs associated with the resources may often inhibit 'efficiency-enhancing' reallocations (Cole and Grossman, 2000). Environmental governance is also influenced by factors such as the nature and use of environmental resources, as well as the nature of arrangements in place to direct the use of such a resource (Paavola \& Adger, 2002).

Cooperative governance or collective action is defined as the "willingness to pool resources, offset the costs of control and increase efficiency through a cooperative atmosphere by, for example, increasing the sense of responsibility among human actors in a firm" (Lieberherr, 2009: 13). It is argued that collective groups, such as water users associations, can process and use information more effectively and efficiently than a centralised system as they generate customs and social conventions that fit their needs in an effort to maximise efficient resource use (Brousseau \& Glachant, 2002; Menard \& Shirley, 2005; Kirsten et al., 2009; Lieberherr, 2009).

Proponents of collective action argue that individuals often do not possess perfect information, as per the assumptions of neoclassical economics, but they are capable of absorbing knowledge through interaction in a particular setting (Ostrom, 2011). This serves as an effective path for achieving sustainable development, equitable distribution and allocation of public goods as well as internalising ecological externalities such as pollution. According to Ostrom (2004), communication and proper involvement of institutions concerned could help policymakers achieve desirable results from collective action.

Contracts are used as one of the essential analytical tools by new institutional economists (Williamson, 1991; North; 1990). As analytical tools, contracts are used to analyse transactions between entities as well as their relationships. They are used as a way of mitigating transactional hazards and improving the quality of services exchanged by the parties (Brousseau, 2008; Mihau et al., 2008). However, the success or failure of contractual agreements depends largely on the nature of the institutional environment within which they have been endorsed. For this reason, it is argued that contracts are "embedded in an institutional framework" (Brousseau, 2008: 38). The enforcement of contracts is thus constrained by the existing institutional environment.

The concept of 'path dependency' is used to describe the adaptation of historical experiences, behaviours and/or identities that once proved to be effective and efficient in new tasks and challenges (Lowndes, 2005; Heinmiller, 2009). Neoclassical economists use the concept of increasing returns to describe path dependency.

\section{Materials and Methods: Social Learning and Transdisciplinarity}

This research is part of a broader transdisciplinary research body from which data was largely drawn. Transdisciplinary research transgresses boundaries between various disciplines and affords the podium through which researchers transcend their own disciplines to "inform one another's work, capture complexity, and create new intellectual spaces" (Gehlert, 2010). The researcher worked closely with researchers from the Institute for Water Research who had conducted various studies in the Lower Sundays River Valley and were knowledgeable about the study area. As part of the social learning process, the researcher attended monthly transdisciplinary research group meetings. The meetings provided a platform within which researchers working on water related issues from different disciplines shared ideas, case study facts and references. The meetings played a major role in creating a link between the case study, the research questions and the overall research approach. 


\subsection{Key Informant Interviews}

Key informants of the study provided insights into water management instruments, institutional frameworks and programmes that are currently in place and/or needed to ensure sustainability, efficiency and equity in the allocation and management of water in the Lower Sundays River Valley. The main informants in this study were the Chief Executive Officer (CEO) of the LSR-WUA and an emerging farmer who has been involved in small scale commercial farming in the area for over five years. The CEO represented the management and administrators of the LSR-WUA. His major role in the study was to give insights into management issues affecting the association. The emerging farmer interviewed gave a different organisational landscape or view about the LSR-WUA as an organisation.

\subsection{Quantitative and Qualitative Research}

In this study, certain indicators of efficiency prompted the use of quantitative data. The main sources of quantitative data for this study were the LSR-WUA's annual financial reports for financial years 2008/2009, 2009/2010, 2010/2011 and 2011/2012. These reports were obtained from the LSR-WUA's official website. The financial reports were used to examine the financial balances and fiscal sustainability of the LSR-WUA in order to evaluate the association's efficiency in its operations. Analysing efficiency in terms of trends in expenditure and income necessitated the use of quantitative data. The use of expenditure and income served as measures of allocative efficiency. The data were inflated to current 2016 prices using the Producer Price Index provided by Statistics South Africa.

A broad range of literature and/or documents, such as water policy documents for the Republic of South Africa, reports, books, journal articles, maps and charts and survey data, among others. The influence of economics on the current institutional and governance arrangement in the Lower Sundays River Valley was investigated through both the selection of appropriate institutional frameworks using the literature, and the application of the framework to the institutional and governance analysis of the work of Clifford-Holmes (2015) and Clifford-Holmes et al. (2013).

\section{Results and Discussions}

\subsection{Historical Institutional Context}

The Sundays River Irrigation Board was established through an Act of Parliament in 1917, with the fundamental aim of constructing Darlington Dam (formerly known as Lake Mentz). The government of the time provided funds in the form of a loan to finance the dam building project (LSR-WUA, 2014). The loan repayment was the responsibility of the irrigators. They raised funds through paying a canal levy imposed by the Irrigation Board in order to repay the loan. The Sundays River Irrigation Board was established solely for the benefit of the irrigators. The elected Irrigators served as Board members for a period of time prescribed by the Sundays River Irrigation Board's constitution. In addition to ensuring that the canals were well maintained and operational, the board members were also responsible for performing financial and administrative responsibilities (LSR-WUA, 2014). Furthermore, the board members had to draft policies enforced by the 1913 Land Act to the specification of their localities.

In August 2004, the Sundays River Irrigation Board was transformed into the Lower Sundays River Water Users Association (LSR-WUA) to operate in terms of National Water Act, 1998 (Act No 36 of 1998) (RSA, 1998; LSRWUA, 2004). According to the Association's constitution, which was prepared in accordance with the requirements of Sections 91(1)(f), 93(1) and 94(2) of the National Water Act of 1998, some of the objectives of the LSR-WUA are to: ensure fair, equitable and efficient distribution of water to all members; improve access to water in previously disadvantaged communities; ensure efficient and consistent distribution of water by maintaining infrastructure in order to minimise water loss; promote efficient water use through capacity building; and encourage environmental management within its area of jurisdiction (LSR-WUA, 2004).

Subsequent to transformation, the LSR-WUA "retained all of the staff from the Irrigation Board" (LSR-WUA, 2014). Furthermore, the LSR-WUA was founded by elected members of the Sundays River Irrigation Board (LSRWUA, 2004). The decision of the LSR-WUA to entrust former Sundays River Irrigation Board members with LSR-WUA duties was largely influenced by section 98(3)(c) of the National Water Act of 1998, wherein it is stated that "any person holding office with a [an irrigation] board when this Act commences continues in office for the term of that person's appointment".

The Association still upholds the vision of providing expert-driven water supply services using operational and efficient infrastructure which was upheld by the Sundays River Irrigation Board before the promulgation of the National Water Act of 1998. By implication, the current and future decisions made by the LSR-WUA are not 
independent from those made in the past under Sundays River Irrigation Board. In essence, the LSR-WUA preserved the status quo following its transformation from Sundays River Irrigation Board. It can hence be argued that the LSR-WUA displays a classic case of path dependency.

In South Africa's water sector, the clash of interests between various stakeholders is common (Naster \& Hansen, 2009). While the upper-regime levels has successfully embraced the principle of integrated water resource management (IWRM) in enactment of both the White Paper on a National Water Policy for South Africa of 1997 and the National Water Act of 1998, the lower-regime levels are yet to fully experience transition. Naster and Hansen (2009) argue that the concept of path dependency offers a deeper understanding of barriers to transition in South Africa's water sector. The argument is that previously disadvantaged and marginalised groups, such as rural households and emerging farmers, continue to be left behind because well-resourced stakeholders have superior leverage in the decisions of catchment management agencies and consequently water users associations (Dent, 2009; Kemerink et al., 2013). For the purposes of this study, emerging farmers are "small-scale farmers who have a water license or who are supposed to obtain one soon" (Faysse, 2004: 6). This definition is used to define such groups within the water users associations of South Africa.

It is further argued that the failure of the Department of Water Affairs to acknowledge the importance of analysing "knowledge equity" instead of focusing solely on "representative equity" at the reform phases in the water sector has resulted in the existence of persistent leverage by well-resourced players (Dent, 2009; Naster \& Hansen, 2009; Kemerinket et al., 2013). Recognition of knowledge equity necessitates the upper-regime level institutions to acknowledge empowerment of previously disadvantaged groups as a pressing priority prior to the establishment of catchment management agencies and water users associations. Financial and technical skills development is necessary for empowering local governments and emerging farmers in order to eliminate the existing economic, technical and legal leverage of the commercial farmers in water users associations and tilt the decision-making scale towards greater equity.

Although cooperative governance forms the core of the National Water Act, translating the principle to practice has proven to be difficult due to the failure of the sector to establish both meaningful stakeholder participation and effective integration simultaneously. The National Water Policy needs to acknowledge that factors such as old and effective networks, vested interests, existing formal or informal contractual water entitlements, and sunk costs towards canals, pipelines and other infrastructure, make it difficult for institutions to deviate from the path set in the past. According to institutionalists, influential parties in institutions are most likely to inherit historical paths, for as long as their powers and inherent institutional efficiencies are not compromised (Sehring, 2009; Heinmiller, 2009).

\subsection{Lower Sundays River Water Users Association-Sundays River Valley Municipality Interactions}

In post-apartheid South Africa, the National Water Act of 1998 called for the transformation of irrigation boards to more democratic, inclusive and representative water users associations (RSA, 1998). Local government is now tasked with the responsibility of service delivery in the form of ensuring sufficient provision of water services to all users (D'Hont et al., 2013). The LSR-WUA has a water quota of $9000 \mathrm{~m}^{3} / \mathrm{ha} / \mathrm{a}$ to be allocated to commercial farmers within area of 16664 ha (Clifford- Holmes et al., 2013).

The Sundays River Valley Municipality receives approximately $3 \%$ of all the LSR-WUA's allocations as per order placement procedures, which it then treats before distributing it as potable water largely for domestic use (D'Hont et al., 2013). The municipality is incorporated as a "user" by the LSR-WUA, and hence it is represented by a nominated member who serves in the Management Committee of the Association. By implication, the interactions between the Sundays River Valley Municipality and the LSR-WUA are governed by both the National Water Act of 1998 and the LSR-WUA constitution (RSA, 1998). By extension, as a water service provider, the Sundays River Valley Municipality's decisions are governed by the Water Services Act of 1997, as well as the Strategic Framework for Water Services (RSA, 1997). Since the municipality acts as both a water service provider and water service authority, a service contract must be instituted in order to allow for self-regulation between the operations of the water service provider and water service authority.

The Sundays River Valley Municipality, however, is struggling to ensure continuous provision of water services to all users within its jurisdiction. One of the contributory factors to this challenge is the lack of a contract between the LSR-WUA and the Sundays River Valley Municipality necessary for governing their operations (D'Hont et al., 2013). According to Clifford-Holmes et al. (2013: 6), the refusal of the LSR-WUA to formulate a binding contract between itself and the Sundays River Valley Municipality is based on the argument that, 
"[T] he WUA treats all users the same, and does not require a contract between itself and a particular user - interactions are mandated by the constitution, facilitated and carried out by the WUA staff and overseen by the Management".

However, a water resource supply contract needs to be in place to govern the activities of the Sundays River Valley Municipality and the LSR-WUA by outlining the terms and conditions of raw water delivery, and the responsibilities and roles to be played by each party. In essence, there are institutional arrangements missing between the Sundays River Valley Municipality and the LSR-WUA. Moreover, the Sundays River Valley Municipality representative neither attends the Management Committee meetings regularly, nor was he elected based on qualifications other than his knowledge on "how to handle those white commercial farmers" (CliffordHolmes et al., 2013: 7) currently serving in various capacities in the LSR-WUA. Another contributory factor is the lack of sufficient water storage to meet the water demand in the municipal jurisdiction.

\subsection{Theoretical Analysis of the Existing Interactions between the Lower Sundays River Water Users Association and the Sundays River Valley Municipality}

It has been argued that government and water institutions often assume that representing the interests of various societal groups in establishments such as water users associations will automatically lead to improved water resource management and equity (Wester et al., 2003; Kemerink et al., 2013). However, water institutions comprise of various stakeholders with divergent and competing interests (Cleaver, 2000; Goldin, 2008). Water institutions within the Lower Sundays River Valley catchment are not an exception. The failure to acknowledge such competition consequently leads to failure to notice the sources of the discrepancies in institutional arrangements. The interdependencies of economic agents need to be recognised by water resource institutions.

Essentially, the Coase theorem has important implications for problems of legal-economic policy because it implies that where stakeholders' actions are not bound by contract, bargaining is almost impossible, and law and policy do not matter in instances where parties can easily determine and choose water uses with the highest returns. The absence of crucial institutional arrangements proposed by the Department of Water Affairs to oversee the interactions between the Sundays River Valley Municipality and the LSR-WUA shows that government institutions do not always have the capacity to instigate water policies in order to avoid catastrophes such as unreliable water supply to end users.

Government institutions often fail in their duties as regulators in the water sector because they have been unsuccessful in recognising the primary interests of user groups within catchments. It can be argued that the lack of success can be attributed to the failure to appreciate that establishing water users associations cannot automatically substitute for the domains of interactions, which existed within irrigation boards. In fact, the establishment of water users associations contributes to complexity in the water sector as they lead to the "coexistence of different domains" (Kemerink et al., 2013: 245). This coexistence of different domains consequently leads to overlapping institutional functions, missing institutional arrangements between parties and general fragmentation of water institutions.

There is a need to analyse representation and inclusion within the various domains of interaction that deal with water allocation. Actors in the water sector are generally constrained by institutional arrangements that were designed to attain Pareto-optimal solutions for the influential few such as irrigation boards. The irrigation boards' primary objectives of maximising individual farmer's payoffs cannot be replaced by the social welfare objectives imposed by the National Water Act overnight (Wester et al., 2003).

\subsection{Lower Sundays River Water Users Association: Equity Considerations}

According to section 4.1 of the LSR-WUA constitution, the Association is committed to regulating the distribution of water in a fair and equitable fashion for all its users (LSR-WUA, 2003). In the financial year 2011/2012, there were more than 400 users registered with the LSR-WUA (LSR-WUA, 2013). The three equity indicators, which will be used to analyse the performance of the LSR-WUA are: responsiveness of the water institutional arrangements to the needs of lower income groups (Boyne, 2002), the sensitivity of institutional arrangements to local needs, and enhanced opportunities for social inclusion (Andrews \& Entwistle, 2010).

The choice of the indicators is not only influenced by the requirements for establishing water users associations enshrined in the National Water Act of 1998, but also by new institutional economics theory and/or frameworks. Water users associations have been entrusted with pursuing responsibilities such as empowering historically disadvantaged groups and/or individuals, promoting equitable water distribution, as well as promoting democracy and "representativity" (Orne-Gliemann, 2008). 


\subsection{Responsiveness to the Needs of Disadvantaged Groups}

Water users associations were created to bring together diverse users such as municipalities, emerging farmers, commercial farmers, and recreational and conservation bodies to ensure equity and cooperation amongst local water users (RSA, 1998; Orne-Gliemann, 2008). However, maintaining equity and responsiveness to the needs of disadvantaged users remains a challenge in some water users associations in South Africa (Orne-Gliemann, 2008; van Steenbergen, 2013). LSR-WUA is not an exception.

In his Chairperson's overview for financial year 2013/2014, Mr Myers, the Chairperson of LSR-WUA noted that they are yet to expand considerably the representation of emerging farmers in the Managing Committee of the Association (LSR-WUA, 2013). He also noted that LSR-WUA is yet to establish and promote its communication with emerging farmers in order to ascertain long-term mutual benefits between the farmers and the Association (LSR-WUA, 2013). Lack of adequate representation of emerging farmers in the Managing Committee may consequently lead to inadequate responsiveness to their needs. The bargaining capacities and influential powers of commercial farmers subsequently count against the interests of emerging farmers as a result (Orne-Gliemann, 2008; Brown, 2013).

The disincentive of commercial farmers and/or the LSR-WUA to go out of their way to accommodate the water and farming needs of the emerging small-scale farmers stems from the institutional and financing architecture of water users associations. This point is addressed in depth and substantively in this research below under the section discussing the difficulty of entering into service level contract(s) between Sundays River Valley Municipality and LSR-WUA.

The National Water Act of 1998 calls for a "balanced representation in terms of the various categories of users" (RSA, 1998). However, as stated by Kemerink et al. (2013), the concept of balanced representation proposed by the National Water Act remains loosely defined. According to Kemerink et al. (2013), it is not clear whether the categories of balanced representation referred to by the National Water Act mean demographic groups, specific gender groups or the so called disadvantaged groups.

In an interview, with an official from the LSR-WUA, conducted during the course of this research, the ambiguity of the meaning of balanced representation came out through the responses of the representative. When asked about the representation of emerging farmers in the LSR-WUA, the Association's representative responded,

"The organisation is divided into seven wards. Six wards are for commercial farmers and one ward is for emerging farmers. There are emerging farmers' representatives in every ward. There is one representative per ward in the six wards for commercial farmers, and there are three representatives in the seventh ward, which is for emerging farmers. Of all the nine representatives, four are black and five are white" (LSRWUA representative, Pers. Comm. 2014).

The response given by the LSR-WUA representatives reflects that the Association defines 'balanced representation' using racial groups and not gender. When asked about his general opinions about the representation of emerging farmers within the LSR-WUA, the interviewed emerging farmer argued that,

"Having a representative within the Association gives us [emerging farmers] the voice and the platform to communicate our concerns. It also helps because we get mentorship in various forms. But we [emerging farmers] do not have the power to influence the decisions on charges and other things made by commercial farmers. Remember, big commercial farmers run the Association" (Emerging Farmer, Pers. Comm. 2014).

The response of the emerging farmer is in line with the theory on path dependency and unequal power relations as well as with the argument posed by Kemerink et al. (2013: 252),

"Securing a seat on a WUA management committee does not automatically mean that the views and interests of historically disadvantaged individuals are represented in the newly established management structures: elements such as authorization, accountability, expertise and resemblance (here defined as the extent to which people feel alike and associated with each other) play a major role in the effectiveness of representation."

Wellman's (2008) study on water users associations in the Olifants-Doorn water management area, established that mere inclusion of emerging farmers and previously disadvantaged individuals in the board of the water users associations does not guarantee equity in the decision-making processes. One of the reasons for the discrepancy was a lack of confidence and knowledge amongst previously disadvantaged members about the operations of water users associations. 


\subsection{The Sensitivity of Institutional Arrangements to Local Needs and Enhanced Opportunity for Social Inclusion}

By virtue of being a potable water supplier for small-scale domestic use, Sundays River Valley Municipality needs to be treated differently from other users within the LRV-WUA (Clifford-Holmes et al., 2013). The responsibility of providing reliable water supply to end users necessitates the need for contractual agreements between the Sundays River Valley Municipality and the LSR-WUA in order to ensure that problems of interrupted water supply are eliminated. However, 'governance gaps' that currently exist between the two institutions have rendered both the Sundays River Valley Municipality and LSR-WUA insensitive to the need of the local residents (CliffordHolmes et al., 2013). Clifford-Holmes et al. (2013: 7) state that

"When the operational issues pertaining to the Kirkwood system were raised, the Department of Water Affairs assessors challenged the [Sundays River Valley Municipality], saying that the WUA is a service provider to the municipality and since the [Municipality] is the water service authority, they should be regulating the WUA's supply."

The lack of an operational contract between the LSR-WUA and the Sundays River Valley Municipality has led to some degree of confusion towards the institutional operations and responsibilities of the two institutions. Worse still, the institutional distinctions created by water policy frameworks remain blurred in the Lower Sundays River Valley. According to Clifford-Holmes et al. (2013), one of the contributory factors to such a discrepancy is little and/or no incentive by the institutions to maximise the gains of establishing effective interactions that would enable sensitivity to local water supply needs. The LSR-WUA has little incentive to change the operation's status quo established by the Sundays River Irrigation Board, while the Sundays River Valley Municipality has little incentive to take an active role in participating in the Managing Committee and general operations of the LSR-WUA.

New institutional economists argue that institutions, such as incentive systems, dictate the actions of parties involved (Lieberherr, 2009). Contracts enforcing institutions are therefore necessary for creating incentives for the establishment of institutional arrangements that are both socially inclusive and sensitive to the diverse needs of all individuals (Greif, 2005; Lieberherr, 2009). Such institutional arrangements are necessary for offsetting potential rent-seeking behaviour, discriminatory vested interests as well as power abuse by the historically advantaged (Greif, 2005; Menard \& Shirley, 2005; Lieberherr, 2009).

\subsection{Lower Sundays River Water Users Association: Efficiency Considerations}

The National Water Act of 1998 has tasked the management committees of water users associations with the responsibilities of maintaining financial and accounting records, ensuring that the records truthfully represent the operations of the associations, and to safeguard the integrity of the associations' financial statements (RSA, 1998; LSR-WUA, 2012). Correspondingly, the LSR-WUA's managing committee has diligently performed the tasks bestowed on them by releasing comprehensive and externally audited financial statements over the years (LSRWUA, 2008, 2009, 2010, 2011 and 2012).

While the LSR-WUA has experienced a growth in its total expenses over the past four years, the Association has maintained positive financial balances over the period as summarised in Figure 1. The figure shows that the net income of LSR-WUA has been consistently growing for the past four years. It can hence be argued that the Association is at least solvent, which is important for their continued operation. This could be attributed to the budgeting and reserve funds practices of the Association. The reserve funds are kept to cater for large costs such as canal replacement (LSR-WUA, forthcoming).

According to Downes (2013), the budgeting process is generally viewed as a transaction cost minimisation measure if it is displays fiscally sustainability, budget transparency and budget participation. Effective and sound budgeting systems are argued to be crucial for attaining increased efficiency in the operations of the institutions (Nee, 2003; Gandhi and Crase, 2009). Williamson (1998 and 2000) argues that budgeting, as a transaction cost minimising measure, is necessary for developing governance structures and organisational boundaries within which the institution can generate profits. 


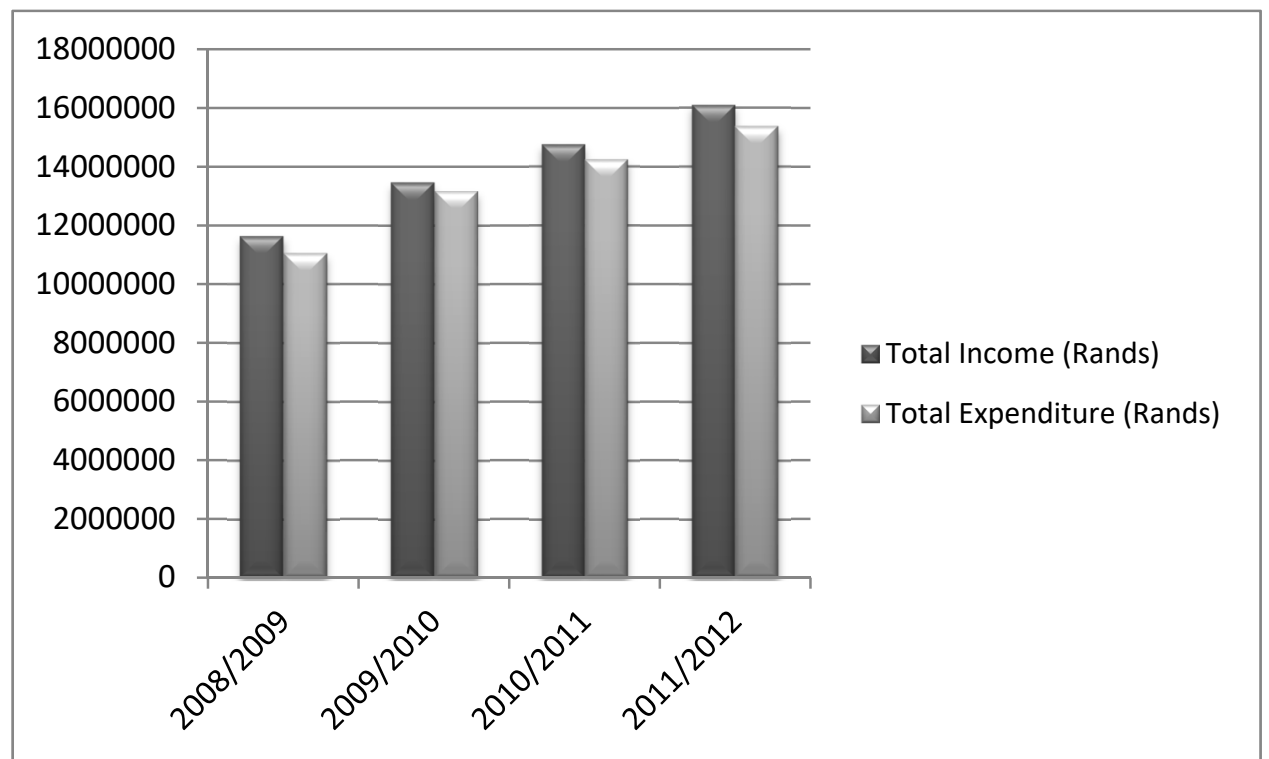

Figure 1. Total income and total expenditure of LSR-WUA between 2008 and 2012. Figures are in 2010 Rands, using Producer Price Index (PPI) provided by Statistics South Africa (Source: LSR-WUA, 2008, 2009, 2010, 2011 and 2012)

According to the Association's 2009 and 2010 annual reports, the LSR-WUA prides itself with "sound" and "well controlled" finances (LSR-WUA, 2009) and "intense management" (LSR-WUA, 2010). Furthermore, the Association has provisions for financial sustainability in the form of various funds such as the capital reserve funds, maintenance funds and contingency reserve fund (LSR-WUA, 2008, 2009, 2010, 2011 and 2012). The interviewed emerging farmer seems to agree that the LSR-WUA financial affairs are well managed. In his response, the representative held,

"I have no problem with the Association's budgeting and finances. They have accountants and experts, so I am not complaining. But I can barely afford to cover water costs in some periods. There is a rumour that the rates are going up again, how worse is it going to be?" (Emerging Farmer, Pers. Comm. 2014)

The efficiency versus cost-effectiveness paradox seems to emerge within the LSR-WUA. For instance, in his 2011/2012 Chairman's Overview, Mr Myers highlighted that the Managing Committee of the LSR-WUA had adopted new governance and compliance systems which were not going to result in reduced costs, but which would "certainly serve to contribute to more effective control and general efficiency of our operation" (LSR-WUA, 2011). According to one of the Association's reports, the management of the LSR-WUA aims to improve operational efficiency in the water supply system through the following:

"Losses in the system are reduced to the minimum and currently a mathematical model and related field measurements are being developed so achieve better water-management control. This model will assess administrative and physical distribution efficiency by measuring the volume of water that was requested against the volume of water that was brought into the system and the volume that can be accounted for delivered at farm-gate sluice" (LSR-WUA, forthcoming).

Similarly, in his 2012/2013 Overview, the Mr Myers mentioned the LSR-WUA has established ways through which water-workers could achieve water supply efficiency and the Association would in turn cover the costs of operations through increasing user charges (LSR-WUA, 2012). A representative from the LSR-WUA revealed, through an interview, that the Association can perform a charge assessment in an effort to cover its expenditures, "all users are aware of that" (LSR-WUA representative, Pers. Comm. 2014).

In his overview, Mr Myers emphasised that the question that emerges from operational efficiency developments is

"What better level of service do I expect and am I prepared to pay the higher costs involved in delivering this level of service?" (LSR-WUA, 2012). 
Cost-effectiveness is achieved when the institutions fulfil their targets at the minimum possible cost (Gleick et al., 2011). Williamson (1998) argues that cost economisation is a necessary tool for ensuring sustainability of the institution. He further argues that often, the objectives of reducing transaction costs and attaining cost-effectiveness are in tension (Williamson, 1998). Theoretically, efficiency is attained when water charges are set at the marginal cost as this serves as a signal of the value of the water used to users (Haas et al., 2011). However, setting water prices at the marginal cost is more useful if institutional arrangements and local conditions are factored in while pricing.

In as much as institutions are encouraged to recover their costs and to invest in both maintenance of water infrastructure and profitable water development projects, cost-effectiveness should always be maintained (UNESCO, 2012). High water charges may consequently infringe on the right to access of water, especially of the poor households and emerging farmers (Grimble, 1999; UNESCO, 2012). As Rogers et al. (2002: 2) argue, increasing the water charges is regressive, and it broadness social inequities because of the "typical price and income elasticities for water and the typical income distributions encountered".

Essentially, the positive financial trends of the LSR-WUA reflect the Association's financial prudence and sustainability. It can hence be argued that the positive financial balances of the Association reveal the ability of the institution to withstand and/or offset the dynamic problems it may face from time to time. This satisfies North's (1990) basic definition of efficiency. However, using the extended definition of efficiency in new institutional economics, where effectiveness is a necessary condition to achieving efficiency, it can be concluded that the LSRWUA's operations are not efficient. This definition is consistent with the National Water Act requirement that ancillary functions should only be performed by water users associations mandated to perform the water services functions and with the resource capacity sufficient for the successful execution of their principal functions (RSA, 1998). The high water charges imposed on emerging farmers is more likely to affect their productivity and profitability, hence failing to fulfil some of the main objectives of the Association. As argued, it is more important for institutions to do what they have proposed well, than to do well something else that was not necessarily proposed (Mihaiu et al., 2010). By implication, it is more important for the LSR-WUA to perform its principal functions well than to do well in its secondary functions.

\subsection{Lower Sundays River Water Users Association: Effectiveness Considerations}

Treating water as a both social and economic good necessitates water institutions to develop conflict resolution mechanisms and transparent structures that promote accountability, communication, civil society participation and other measures of effectiveness. According to Saleth and Dinar (2004: 11),

"The crisis in the water sector has also revealed the inherent limitations of today's institutions in dealing effectively with the new set of problems related more to resource allocation and management than to resource development."

Water users associations need to treat water users as clients, not just beneficiaries (Saleth and Dinar, 2004). This requires them to craft measures that balance the supply and demand for water resources through defining rules for water allocation, development and use in an effective way. In new institutional economics, however, the term "effectiveness" remains difficult to define (Lieberherr, 2009). This is because in new institutional economics, effectiveness is considered an outcome of efficiency. Considering effectiveness as merely an outcome of efficiency implies that minimising transaction costs directly translates to effectiveness.

Essentially, focusing on minimal transaction costs as a key way of defining effectiveness makes it difficult and almost impossible to disentangle effectiveness from efficiency (Lieberherr, 2009). Some scholars, however, have developed a quantitative framework within which the effectiveness of water institutions can be evaluated (Roger and Hall, 2003; Menard and Saleth, 2011). Such scholars define effectiveness as,

"The existence of the best feasible institutions (that are the outcome of individual choices), which increase the enforceability of contracts." (Lieberherr, 2009: 20)

The indicators identified within the quantitative framework allow for an independent analysis of effectiveness without necessarily solely depending on transaction-costs and efficiency (Roger and Hall, 2003; Menard and Saleth, 2011). Table 1 summarises the indicators. 
Table 1. Effectiveness indicators and their application to the LSR-WUA case

\begin{tabular}{|c|c|}
\hline Effectiveness Indicator & Application to LSR-WUA \\
\hline Transparency & $\begin{array}{l}\text { - Annual general meetings are held as per the requirements of the National Water Act of } 1998 \\
\text { and the LSR-WUA constitution and are open for all water users. } \\
\text { - } \quad \text { Minutes of the previous annual general meeting are circulated and confirmed by all users } \\
\text { beforehand. } \\
\text { - } \quad \text { Financial statements are circulated beforehand. Water users can ask for clarity, reject or } \\
\text { accept and/or approve the statements in their form. } \\
\text { - Annual reports are circulated before the annual general meeting and water users can ask for } \\
\text { clarity at any date before the announced date of the annual general meeting. }\end{array}$ \\
\hline Accountability and regulation & $\begin{array}{l}\text { - The Management Committee has to operate according to the prescribed functions in the } \\
\text { National Water Act of } 1998 \text { and the LSR-WUA constitution. } \\
\text { - } \quad \text { Non-performing members are to be disqualified according to Schedule } 4 \text { of the National } \\
\text { Water Act. } \\
\text { - } \quad \text { Annual financial statements are internally and externally audited in accordance with Section } \\
33 \text { (1) of the National Water Act. } \\
\text { - } \quad \text { Financial statements are prepared as per International Reporting Standards. }\end{array}$ \\
\hline Communication & $\begin{array}{l}\text { - } \quad \text { Notices are communicated to the members through letters and the Association's website. } \\
\text { - As at April 2014, the events calendar for } 2014 \text { has not been updated in the website. However, } \\
\text { the annual reports and financial statements were up to date. }\end{array}$ \\
\hline Civil society participation & $\begin{array}{l}\text { - The Sundays River Valley Municipality representative in the Management Committee acts as } \\
\text { an intermediary between the Association and the municipality, and subsequently potable water } \\
\text { users. } \\
\text { - Clifford-Holmes et al., (2013) note that "despite occupying a seat on the management } \\
\text { committee, the Sundays River Valley Municipality representative rarely attended [meetings prior } \\
\text { mid-2012]" }\end{array}$ \\
\hline
\end{tabular}

Using these indicators, it can be concluded that the LSR-WUA arguably displays transparent, and accountable regulatory governance. The committee is responsible for budgeting, compiling reports and project planning, among other functions (LSR-WUA, 2012). It is argued that stakeholder participation in the budgeting and project planning processes leads to improved effectiveness of the institution (WPP, 2002; Roger \& Hall, 2003; Menard \& Saleth, 2011).

Furthermore, the Management Committee consists of representatives for various users. This implies that the committee consists of people with diverse interests. New institutional economists argue that cooperative governance is inefficient in reacting promptly to shocks and accumulating capital due to complexities associated with managing incentives of individuals with divergent and varying interests (Menard \& Shirley, 2005; Brousseau \& Glachant, 2008). It is further argued that cooperative governance often leads to blame shifts between agents (Menard \& Shirley, 2005). The blame shift problem seems to exist in the Lower Sundays River Valley.

The representative of the LSR-WUA cited the "blame game" as one of the main challenges faced by the Association. He highlighted:

"One of the main challenges faced with the stakeholders in the Valley is 'blame game'. Because there are so many institutions and people involved, it is very easy to play the blame game. That is why there is a lot of, "We didn't do anything wrong, you are wrong and because of you we don't have the water!" in the Valley."

The lack of formal service level agreements between the LSR-WUA and other stakeholders, particularly the Sundays River Valley Municipality has consequently led to the absence of clear areas of responsibility and mechanisms of enforcing agreed obligations. This greatly increased transactions costs associated with continual negotiation and led to conflict in which no one accepted responsibility, and subsequently the "blame game" for service delivery failure. Furthermore, there seems to be an existing degree of doubt concerning the technical capabilities of municipal officials among consulting engineers who interacted with the Sundays River Valley Municipality (Clifford-Holmes, 2015). Such stakeholders justify the blame shift by offering racial explanations. 
In this regard a retired engineer was quoted by Clifford-Holmes (2015: 59) stating that, "These black officials only know how to do one thing - and that's break infrastructure (sic)".

The problem of blame-shifting from one agent to the other seems to be common in the water issues in South Africa. In the National Development Plan (NDP), it is extensively argued that:

"Example of what happens when the water in a town is found to be undrinkable. The media blames the Minister of Water Affairs. The community blames the mayor. The mayor blames the head of the water utility. The head of the water utility blames the technical engineer. The engineer says that the maintenance budget has been cut for the past three years and now the water is undrinkable. The head of finance in the municipality says that the budget was cut because personnel costs have crowded out maintenance expenditure. The mayor argues that the salary structure is negotiated at a national level by the level by the South African Local Government Association. The Association says that municipalities can opt out of these agreements if they are unaffordable. And so on. " (NDP, 2011: 51-52)

New institutional economics scholars argue that in a cooperative governance setup, agents often fail to cooperate and clear lines of power relations are often visible (Reuben, 2003; Ostrom, 2004; Brown, 2013). Scholars argue that heterogeneity of endowments, as well as homogeneity of identities and interests, are some of the indicators that should be used for gauging the success of water users associations in terms of efficiency, effectiveness and equity (Saleth \& Dinar, 2004; Dinar \& Saleth, 2005; Grafton et al., 2011).

\section{Conclusion}

One of the main goals of this study was to describe the influence of the existing institutional and water governance arrangements in the Lower Sundays River Valley in the efficiency, effectiveness and equity of water allocation in the catchment. This paper answered the research goal though presenting the historical context of the LSR-WUA and discussing how embedded interests and path dependency have shaped the operations of the Association to date. Traditionally, irrigation boards operated as raw water suppliers to commercial farmers. Subsequently, the irrigation boards were called to transform to water users associations. The transformation of the Sundays River Irrigation Board to LSR-WUA exhibits path dependence. Although the LSR-WUA arguably displays transparent, accountable and regulatory governance with an effective and sound budgeting system, the institutional arrangements between the Association and the Sundays River Valley Municipality are less sensitive to local needs.

Furthermore, the paper argues that lack of adequate representation of emerging farmers in the Managing Committee may subsequently result in inadequate responsiveness to their needs. Using the indicators of effectiveness, it is argued that the LSR-WUA arguably displays transparent, accountable and regulatory governance. However, the civil society indicator of effectiveness is not satisfactorily achieved due to lack of regular representation of Sundays River Valley Municipality in the management committee meetings.

\section{Acknowledgements}

This paper is an adaptation of my unpublished MEcon thesis. I wish to acknowledge the comments of my supervisors, Prof Jen Snowball and Prof Garvin Fraser on the earlier version of this paper. The study was supported by postgraduate funding from the Environmental and Resource Economics Research Focus Area (ENREFA), Department of Economics and Economic History, Rhodes University.

\section{References}

Boyne, G. A. (2002). Public and private management: What's the difference? Journal of Management Studies, 39(1), 97-129. http://dx.doi.org/10.1111/1467-6486.00284

Brousseau, E., \& Glachant, J. (2008). New institutional economics- A guidebook. New York: Cambridge University Press

Brown, J. (2013). Can Participation Change the Geography of Water? Lessons from South Africa. Annals of the Association of American Geographers, 103(2), 271-279. http://dx.doi.org/10.1080/00045608.2013.754685

Cavana, R. Y., Delahaye, B. L., \& Sekaran, U. (2001). Applied business research: Qualitative and quantitative methods (Australian ed.). Milton, Queensland, Australia: J. Wiley.

Challen, R. (2000). Institutions, Transaction Costs, and Environmental Policy: Institutional reform for water resources. UK: Edward Elgar Publishing Limited.

Cleaver, F. (2000). Moral ecological rationality, institutions and the management of common property resources. Development and Change, 31(2), 361-383. http://dx.doi.org/10.1111/1467-7660.00158 
Clifford-Holmes, J., Cundill, G., \& Burt, J. (2012). The water supply governance gap in the water services of the Sundays River Valley Municipality and the Lower Sundays River Water User Association. Comprehensive minutes of October 2012 workshop. Workshop 4 of the SANPAD 'Water and Sustainability' project in the Lower Sundays River, (pp. 1-17). Kirkwood.

Clifford-Holmes, J. K., De Wet, C., Slinger, J., and Palmer, C. G. (2013). Governance gaps and operational opportunities: Water Users Associstiond and the challenges of municipal bulk water supply. The Third Southern African Young Water Professional's Conference, 15-18 July. Stellenbosch.

Clifford-Holmes, J. (2015). A transdisciplinary investigation of water governance in the Lower Sundays subcatchment of South Africa. PhD Thesis Rhodes University, Grahamstown, South Africa.

Cole, D. H., \& Grossman, P. Z. (2000). The Meaning of Property “Rights:” Law vs. Economics? Retrieved January 25, 2013, from http://indylaw.indiana.edu/instructors/cole/web\%20page/meaning\%20of $\% 20$ property $\% 20$ rights.pdf

David, P. (1994). Why are institutions the "carriers of history"? Path dependence and the evolution of conventions, organizations and institutions. Structural Change and Economic Dynamics, 5, 205-20.

Deacon, R. T., \& Mueller, B. (2006). Political economy and natural resources. In: Lopez, R., \& Toman, M. A. (eds). Economic development and environmental sustainability- New policy options. Oxford University Press.

Dent, M. (2008). Creating commons to manage commons. Pretoria: Leadership Newsletter No. 77. African Water Issues Research Unit, University of Pretoria.

D'Hont, F., Clifford-Holmes, J. K., \& Slinger, J. (2013). Addressing stakeholder conflicts in rural South Africa using water supply model31st International Conference of the System Dynamic Society. Massachusetts, Cambidge

Faysse, N. (2004). Challenges for fruitful participation of smallholders in large-scale water resource management organisations: selected case studies in South Africa. Agrekon, 43(1), 52-73.

Gandhi, P., \& Crase, L. (2009). New Institutional Economics, Governance and the Performance of Water Institutions in India. International Association of Agricultural Economists Conference. Beijing: China. Retrieved July 2, 2013, from http://ageconsearch.umn.edu/bitstream/51415/2/Contributed-Paper-626Gandhi-Crase-Iaae2009.pdf

Gehlert, S. (2010). Transdisciplinary Functioning in Multi-Level Breast Cancer Disparities Research. Society for Social Work \& Research. Center for Interdisciplinary Health Disparities Research. Retrieved October 12, 2013, from http://www.sswr.org/PCSSWR\%20(FILEminimizer).pdf.

Gleick , P. H., Christian-Smith, J., \& Cooley, H. (2011). Water-use efficiency and productivity: rethinking the basin approach. Water International, 36(7), 784-798. http://dx.doi.org/10.1080/02508060.2011.631873

Goldin, J. (2008). It Takes Two to Tango: Steps Towards Change in the Water Sector. In D. Hemson, Poverty and Water: Explorations of the Reciprocal Relationship. London.

Grafton, R. Q., Libecap, G., McGlennon, S., Landry, C., \& O’Brien, B. (2011). An Integrated Assessment of Water Markets: A Cross-Country Comparison. Review of Environmental Economics and Policy, 5(2), $219-239$.

Grimble, R. (1999). Economic instruments for improving water use efficiency: theory and practice. Agricultural Water Management, 40, 77-82.

Hackett, S. C. (2011). Environmental and Natural Resources Economics: Theory, Policy, and the Sustainable Society. New York: M.E Sharpe Inc.

Healy, M., \& Perry, C. (2000). Comprehensive criteria to judge validity and reliability of qualitative research within the realism paradigm. Qualitative Market Research - An International Journal, 3(3), 118-126. http://dx.doi.org/10.1108/13522750010333861

Heinmiller, B. T. (2009). Path dependency and collective action in common pool governance. International Journal of the Commons, 3(1), 131-147. http://doi.org/10.18352/ijc.79

Henderson, K. A.(2011). Post-positivism and the pragmatics of leisure research. Leisure Science, 33, $341-346$. http://dx.doi.org/10.1080/01490400.2011.583166

Kirsten, J. F., Dorward, A. R., Poulton, C., \& Vink, N. (2009). Institutional economics perspectives on African agricultural development. Springer Science and Business Media. 
Lee, B., \& Cassell, C. (2013). Research Methods and Research Practice: History, Themes and Topics. International Journal of Management Reviews, (15), 123-131. http://dx.doi.org/10.1111/ijmr.12012

Leach, M., Mearns, R., \& Scoones, I., (1999). Environmental Entitlements: Dynamics and Institutions in Community-Based Natural Resource Management. World Development, 27(2), 225-247. http://dx.doi.org/ 10.1016/S0305-750X(98)00141-7

Libecap, G. D. (2006). Transaction Costs, Property Rights, and the Tools of the New Institutional Economics: Water Rights and Water Markets. Tucson: National Bureau of Economic Research.

Libecap, G. D. (1989). Contracting for property rights. New York: Cambrige University Press.

Lieberherr, E. (2009). Policy Relevance of New Institutional Economics? Assessing Efficiency, Legitimacy and Effectiveness. Discussion paper series on the Coherence between institutions and technologies in infrastructures. Retrieved January 28, 2013, from http://infoscience.epfl.ch/record/151644/files/Lieberherr _NIE.working.paper_11.09.pdf

Lowndes, V. (2005). Something old, something new, something borrowed. How institutions change (and stay the same) in local governance. Policy Studies, 26(3-4), 291-309.http://dx.doi.org/10.1080/01442870500198361

LSR-WUA. (2003). Constitution. Sunland: Lower Sundays River Water Users Association.

LSR-WUA. (2008). Annual Report 2007/2008. Sunland: Lower Sundays River Water Users Association.

LSR-WUA. (2009). Annual Report 2008/2009. Sunland: Lower Sundays River Water Users Association.

LSR-WUA. (2010). Annual Report 2009/2010. Sunland: Lower Sundays River Water Users Association.

LSR-WUA. (2011). Annual Report 2010/2011. Sunland: Lower Sundays River Water Users Association.

LSR-WUA. (2012). Annual Report 2011/2012. Sunland: Lower Sundays River Water Users Association.

Menard, C., \& Shirley, M. M. (2012). New Institutional Economics: From early intuitions to a new paradigm? Working Paper. Ronald Coase Institute .

Mihaiu, D. M., Opreana, A., \& C, M. P. (2010). Efficiency, effectiveness and performance of the public secristescutor. Romanian Journal of Economic Forecasting, 4, 122-147.

Naster, M., \& Hansen, M. (2009). Water legislation - what values, which ways? Institutional path dependency and transition management in integrated water resource management in South Africa. The 2009 Amsterdam Conference on the Human Dimensions of Global Environmental Change (pp. 2-4). Amsterdam, Netherlands: LUCID.

Nee, V. (2003). New Institutionalism, economic and sociological. In Smelser, N. and Swedberg, R, Handbook for Economic Sociology (pp. 3-71). Princeton: Princeton University Press.

North, D. C. (1990). Institutions, Institutional Change, and Economic Performance. Cambridge, MA: Cambridge University Press.

Ollila, P. (2009). Principles of institutional economics -With applications to cooperative enterprises. Department of Economics Working Papers no 56. Helsinki University.

Orne-Gliemann, M. (2008). Water User Associations in South Africa: Balancing Flexibility and Clarity. Pretoria: Water Research Commission.

Ostrom, E. (2004). Collective action and property rights for sustainable development-Understanding collective action. Focus 11, Brief 2 of 16.

Ostrom, E. (2011). Background on the Institutional Analysis and Development Framework. The Policy Studies Journal, 39(1), 7-27. http://dx.doi.org/10.1111/j.1541-0072.2010.00394.x

Paavola, J., \& Adger, W. N. (2002). New institutional economics and the environment: Conceptual foundations and policy implications. CSERGE Working Paper EDM 02-06.

Patton, M. Q. (2002). Qualitative Research and Evaluation Methods. California: Sage Publications.

Pegram, G., \& Mazibuko, G. (2003). Evaluation of the role of water user associations in water management in South Africa. Gezina, South Africa: Water Research Commission.

Perret, S. (2002). Water policies and smallholding irrigation schemes in South Africa: a history and new institutional challenges. Water Policy, 4 (3), 283-300.http://dx.doi.org/10.1016/S1366-7017(02)00031-4 
Rogers, P., \& Hall, A. W. (2003). Effective Water Governance. Sweden: TEC Background papers. Global Water Partnership.

Rogers, P., De Silvab, R., \& Bhatia, R. (2002). Water is an economic good: How to use prices to promote equity, efficiency, and sustainability. Water Policy, 4, 1-7.

RSA. (1997). Water Services Act. (Act No. 108 of 1997). Pretoria, South Africa: Government Gazette.

RSA. (1998). National Water Act. Pretoria, South Africa: Government Gazette, 19182. Act 38, 26 August 1998

Saleth, R. M., \& Dinar, A. (2004. A Cross-Country Analysis of Institutions and Performance. Cheltenham, UK: Edward Elgar.

Sehring, J. (2009). Path Dependencies and Institutional Bricolage in Post-Soviet Water Governance. Water Alternatives, 2(1), 61-81.

Sharp, L., McDonald, A., Sim, P., Knamiller, C., Sefton, C., \& Wong, S. (2011). Positivism, post-positivism and domestic water demand: interrelating science across the paradigmatic divide. Transactions of the Institute of British Geographers, Royal Geographical Society (with the Institute of British Geographers).

UNESCO. (2012). Investing in water infrastructure, its operation and its maintenance. Washington, DC: The World Bank.

Van Steenbergen, F. (2013). On Water User Associations (WUAs). The Water Channel. Retrieved January 13, 2014 from http://www.thewaterchannel.tv/thewaterblog/147-on-water

Wellman, G. (2008). Water User Associations in the Olifants-Doorn Water Management Area. Retrieved January 24, 2014 from http://www.spp.org.za/reports/water_user.pdf

Wester, P., Merrey, D. J., \& De Lange, M. (2003). Boundaries of consent: stakeholder representation in river basin management in Mexico and South Africa. World Development, 31(5), 797-812. http://dx.doi.org/10.1016/S0305-750X(03)00017-2

Williamson, O. E. (1991). Comparative Economic Organization: The Analysis of Discrete Structural Alternatives. Administrative Science Quarterly, 36 (2), 269-296. http://dx.doi.org/10.2307/2393356

Williamson, O. E. (1998). The Institutions of Governance. The American Economic Review, 88(2), 75-79.

Williamson, O. E. (2000). The New Institutional Economist: Taking Stock, Looking Ahead. Journal of Economic Literature, 38 (3), 595-613.

\section{Copyrights}

Copyright for this article is retained by the author(s), with first publication rights granted to the journal.

This is an open-access article distributed under the terms and conditions of the Creative Commons Attribution license (http://creativecommons.org/licenses/by/4.0/). 